\title{
The significance of soil moisture in forecasting characteristics of flood events. A statistical analysis in two nested catchments.
}

\author{
Peter Chifflard $^{1 *}$, Julius Kranl ${ }^{2}$, Georg zur Strassen ${ }^{3}$, Harald Zepp ${ }^{2}$ \\ ${ }^{1}$ Department of Geography, Philipps-University Marburg, Deutschhausstr. 10, 35032 Marburg, Germany. \\ 2 Department of Geography, Ruhr- University Bochum, Universitätsstr. 150, Building NA, 44780 Bochum, Germany. \\ ${ }^{3}$ Ruhrverband, Kronprinzenstr. 37, 45128 Essen, Germany. \\ * Corresponding author. Tel.: +49(0)6421 28-24155. Fax: +49(0)6421 28-28950. E-mail: peter.chifflard@geo.uni-marburg.de
}

\begin{abstract}
We examine the feasibility and added value of upscaling point data of soil moisture from a small- to a mesoscale catchment for the purpose of single-event flood prediction. We test the hypothesis that in a given catchment, the present soil moisture status is a key factor governing peak discharge, flow volume and flood duration. Multiple regression analyses of rainfall, pre-event discharge, single point soil moisture profiles from representative locations and peak discharge, discharge duration, discharge volume are discussed. The soil moisture profiles are selected along a convergent slope connected to the groundwater in flood plain within the small-scale catchment Husten $\left(2.6 \mathrm{~km}^{2}\right)$, which is a headwater catchment of the larger Hüppcherhammer catchment (47.2 $\mathrm{km}^{2}$, Germany). Results show that the number of explanatory variables in the regression models is higher in summer (up to 8 variables) than in winter (up to 3 variables) and higher in the meso-scale catchment than in the small-scale catchment (up to 2 variables). Soil moisture data from selected key locations in the small catchment improves the quality of regression models established for the meso-scale catchment. For the different target variables peak discharge, discharge duration and discharge volume the adding of the soil moisture from the flood plain and the lower slope as explanatory variable improves the quality of the regression model by $15 \%, 20 \%$ and $10 \%$, respectively, especially during the summer season. In the winter season the improvement is smaller (up to 6\%) and the regression models mainly include rainfall characteristics as explanatory variables. The appearance of the soil moisture variables in the stepwise regression indicates their varying importance, depending on which characteristics of the discharge are focused on. Thus, we conclude that point data for soil moisture in functional landscape elements describe the catchments' initial conditions very well and may yield valuable information for flood prediction and warning systems.
\end{abstract}

Keywords: Soil moisture; Runoff prediction; Catchment hydrology; Spatial-temporal variability; Multivariate statistics.

\section{INTRODUCTION}

Accurate runoff prediction is of vital interest for any integrated management of water resources and for controlling reservoirs. This calls for reliable functions describing how rainfall is transformed into creek and river discharge depending on the properties of the catchment. The prediction is aggravated by the fact that runoff generation is a highly nonlinear process and threshold processes are observed in many catchments due to the initial conditions (Ali et al., 2015; Chifflard and Zepp, 2008; Chifflard et al., 2004; Penna et al., 2015; Tromp-van Meerveld and McDonnell, 2006a, b; Zehe and Blöschl, 2004). Thus, information describing the wetness of a catchment prior to a flood event is increasingly being introduced into flood warning tools (e.g. Brocca et al., 2009; Bronstert et al., 2012; Graeff et al., 2012). One hydrological variable frequently found to be nonlinearly related to runoff is soil moisture, which impacts the catchment runoff response at the field and headwater scale (Ali et al., 2010; Brocca et al., 2010; Zehe et al., 2010). Typically referred to as antecedent soil moisture, pre-event soil moisture or antecedent wetness condition, the spatiotemporal dynamics of the soil moisture are commonly used to describe the internal state of a catchment which expresses the sensitivity of the catchment to generating surface flow, subsurface flow and to triggering base flow (Bronstert et al., 2012; Casper et al., 2007). The internal status of a catchment can be also expressed easily by e.g. pre-event discharge or antecedent precipitation indices as proxies for the soil moisture. However, these indices do not meet the requirements of a distributed modelling approach
(Graeff et al., 2009; Longobardi et al., 2003). In fact, the application of spatial soil moisture patterns are potentially valuable for calibrating and validating models (Parajka et al., 2006; Rinderer et al., 2012) and the inclusion of locally measured soil moisture data in a conceptual rainfall-runoff model greatly improves flood forecasting, especially during high flow conditions (Aubert et al., 2003; Bronstert et al., 2012). The high spatiotemporal variability of soil moisture monitoring for large areas is not an easy task and hinders the general application of soil moisture assimilation in rainfall-runoff models (Brocca et al., 2009; Bronstert et al., 2012; Chen et al., 2014). Attempts are being made to gather spatially distributed information on the soil moisture status of entire catchments by means of regionalization and remote sensing (Alvarez-Garreton et al., 2014; Massari et al., 2014). The current microwave remote sensing techniques provide the opportunity to measure soil moisture of large areas, but the spatial and temporal resolutions of the observations is too coarse for hydrological applications in small catchments (Alvarez-Garreton et al., 2014; Brocca et al., 2010; Lakshmi, 2013; Wagner et al., 2007). To improve the spatial resolution up to $1 \mathrm{~km}$, different soil moisture disaggregation algorithms have been formulated (e.g. Fang and Lakshmi, 2014; Pellenq et al., 2003), as for which in situ measurements of soil moisture are required for validation. This is extremely ambitious and thus restricted to complex measurement operations. On the other hand, the approaches favoring regionalization are based on the installation of numerous spatially distributed soil moisture sensors (Bogena et al., 2010; Brocca et al., 2009; Bronstert et al., 2012; Casper et al., 2007; Engels et 
al., 2012; Zehe et al., 2010) or on repeated measurement efforts to obtain an adequate number of sampling points (Chifflard et al., 2013; Petrone et al., 2004; Western et al., 2004). Nevertheless, regardless of the method chosen (e.g. time domain reflectometry, ground penetrating radar) these measurements are expensive, time-consuming or both. Thus, major efforts still have to be made to optimize soil moisture networks (Vereecken et al., 2014).

In this context, various attempts have been made to determine both the number of samples needed to predict mean soil moisture content and the optimal placement of soil moisture sensors (Vereecken et al., 2014). A wide range of suggestions exists, anywhere from 3-32 samples (Jacobs et al., 2004) through 15-35 samples (Brocca et al., 2007) and more than 15 samples (Tague et al., 2010), which indicates that these values are site-specific and cannot be regionalized (Vereecken et al., 2014). Brocca et al. (2007) emphasizes that the number of samples required is highly dependent upon topography and increases with complex topographic structures. Zehe et al. (2010) assessed spatial patterns by the definition of soil moisture ensemble units, which are defined as areas that are uniform with respect to soil type, terrain properties, vegetation class as well as rainfall and radiation forcing. They showed that the average antecedent soil moisture of a forested soil moisture ensemble, measured by up to 39 TDR probes within a spatial extent of $100 \mathrm{~m}^{2}$, explained up to $92 \%$ of the observed runoff coefficients at the outlet of a $16 \mathrm{~km}^{2}$ catchment. Therefore, Zehe et al. (2010) conclude that the spatiotemporal highly resolved soil moisture sampling in key landscape units is a valuable opportunity to predict runoff. However, every attempt to forecast and monitor flooding faces the problem of upscaling, be it of the parameters or processes (Ojha et al., 2014). Thus, for enhanced flood warning the challenge in optimizing soil moisture sampling is to place the least number of sensors to retrieve sufficient data, while simultaneously expanding the runoff prediction to a larger spatial scale where additional spatially variable factors, such as rainfall or radiation, impact the spatial soil moisture variability. The principle question in this study is if the soil moisture status of a catchment derived from measurements on the point scale can be upscaled to model the larger catchments. Considering the constraints in retrieving spatially distributed soil moisture data and the necessity of assimilating the originally measured data instead of implementing them directly into deterministic models, we will assess the value of single point soil moisture profiles from representative locations in a catchment to explore soil moisture control on the runoff generation across spatial scales. Therefore we will use multiple linear regression models by using different response variables and predictor variables describing the runoff generation and among others the antecedent moisture conditions, respectively. Aware of the nonlinearity of hydrological processes and the threshold behavior of the rainfall-runoffrelationships the application of linear models to predict catchment's response is an auspicious approach to identify significant predictor variables (e.g., Graeff et al., 2012; Hrnčíř et al., 2010). Blume et al. (2007) emphasize the surprisingly good results by using simple linear interrelationships to predict runoff coefficients, however, they point out that the derived model should not applied outside the range of the predictor variables. In the context of the principle question of this study, the derived multiple linear regression models will show that the integration of a selected number of single point soil moisture profiles located at hydrologically relevant plots will improve the quality of the regression model. Thus, to cover a wide range of aspects determining the catchment's wetness or sensitivity, we selected soils in the floodplain near the creek and at the lower, middle, and upper slope. Whereas the floodplain soil is influenced by the fluctuating groundwater table, the lower slope location is connected to the intermittent subsurface flow through the cover beds of the slope. The middle slope position represents a soil with a high water storage capacity in the fine-textured slope sediments (colluvial beds) and the upper slope is characterized by a shallow soil with bedrock contact. Thus, these soils should have the strongest moisture contrasts between humid and dry periods and cover a typical landscape unit within this catchment as postulated by Zehe et al. (2010). The overall shape of the slope is convergent (Fig. 1), creating flow concentration in the subsoil. We argue that vertical soil moisture profiles at selected locations represent the main features of the spatial variation of the catchment's wetness. Thus depicting the strongest moisture contrasts, we escape the uncertainties of small scale spatial variability in soil moisture. Furthermore, the sequence of locations along the convergent slope connected to the groundwater in the floodplain is an intelligent, process-motivated set-up with a convincing cost-benefit ratio as opposed to complex measurement installations.

We hypothesize that 1) the significance of measurement sites within the discharge generating catchment is more important than the absolute number of measurement sites, 2) under the condition of both rainfall and meso-scale physiographic homogeneity in terms of relief, soils and land use, it is possible to upscale the functional relationships between rainfall and discharge elaborated in a small catchment without loss of predictive reliability and 3) the influence of antecedent soil moisture is greater during the summer than in the humid winter, because spatial patterns are more pronounced during the season with high evapotranspiration than in the winter. On the other hand, spatial rainfall variations are larger in summer, counterbalancing the quality of any prediction model. The question thus arises as to whether the likelihood of predicting discharge characteristics in summer are smaller than in winter.

\section{RESEARCH AREA}

In this study, we apply a nested catchment approach. The catchment Husten $\left(2.6 \mathrm{~km}^{2}\right)$ is a headwater catchment of the larger catchment Hüppcherhammer $\left(47.2 \mathrm{~km}^{2}\right)$ located in the Rhenish Massif (Germany, Province of North RhineWestphalia) between $50^{\circ} 58^{\prime}$ '50.000' and $51^{\circ} 03$ ' $26^{\prime \prime}$ ' northern latitude and $07^{\circ} 44^{\prime} 15.500^{\prime \prime}$ and $07^{\circ} 49^{\prime} 49^{\prime \prime}$ ' eastern longitude (Fig. 1). The gauging station at Hüpcherhammer lies at $313 \mathrm{~m}$ a.s.l., whereas the highest elevation reaches $514 \mathrm{~m}$ a.s.l. The Hüppcherhammer catchment consists of two main channels, the Rose and the Brachtpe, which jointly contribute to the Biggetal reservoir operated by the local water board Ruhrverband. Land use in both catchments is dominated by pasture land and spruce stands and mixed forests. Some arable land and settlements characterize the remaining part of the catchments. Mean annual temperature is approximately $9.1^{\circ} \mathrm{C}$ and mean annual rainfall is approximately $1227 \mathrm{~mm}$, while $15-20 \%$ of the annual precipitation comes in the form of snow (Deutscher Wetterdienst, 2004). Water levels have been observed at the gauging station Hüppcherhammer since 1967 and since 1999 at the gauging station Husten as well, which are both operated by the Ruhrverband. The mean discharge (MQ) is about $1.24 \mathrm{~m}^{3} / \mathrm{s}$ or $828 \mathrm{~mm} /$ year (Hüppcherhammer; 1967-2014) and about $0.078 \mathrm{~m}^{3} / \mathrm{s}$ or 965 mm/year (Husten: 2001-2009; Ruhrverband 2014). The HQ5 reaches $29.6 \mathrm{~m}^{3} / \mathrm{s}$ at the gauge Hüppcherhammer and $2.56 \mathrm{~m}^{3} / \mathrm{s}$ at the gauge Husten. The geology is characterized by sandysilty clay shale from the Lower and Middle Devonian (Grabert and Hilden, 1972). Loamy Cambisols derived of periglacial 


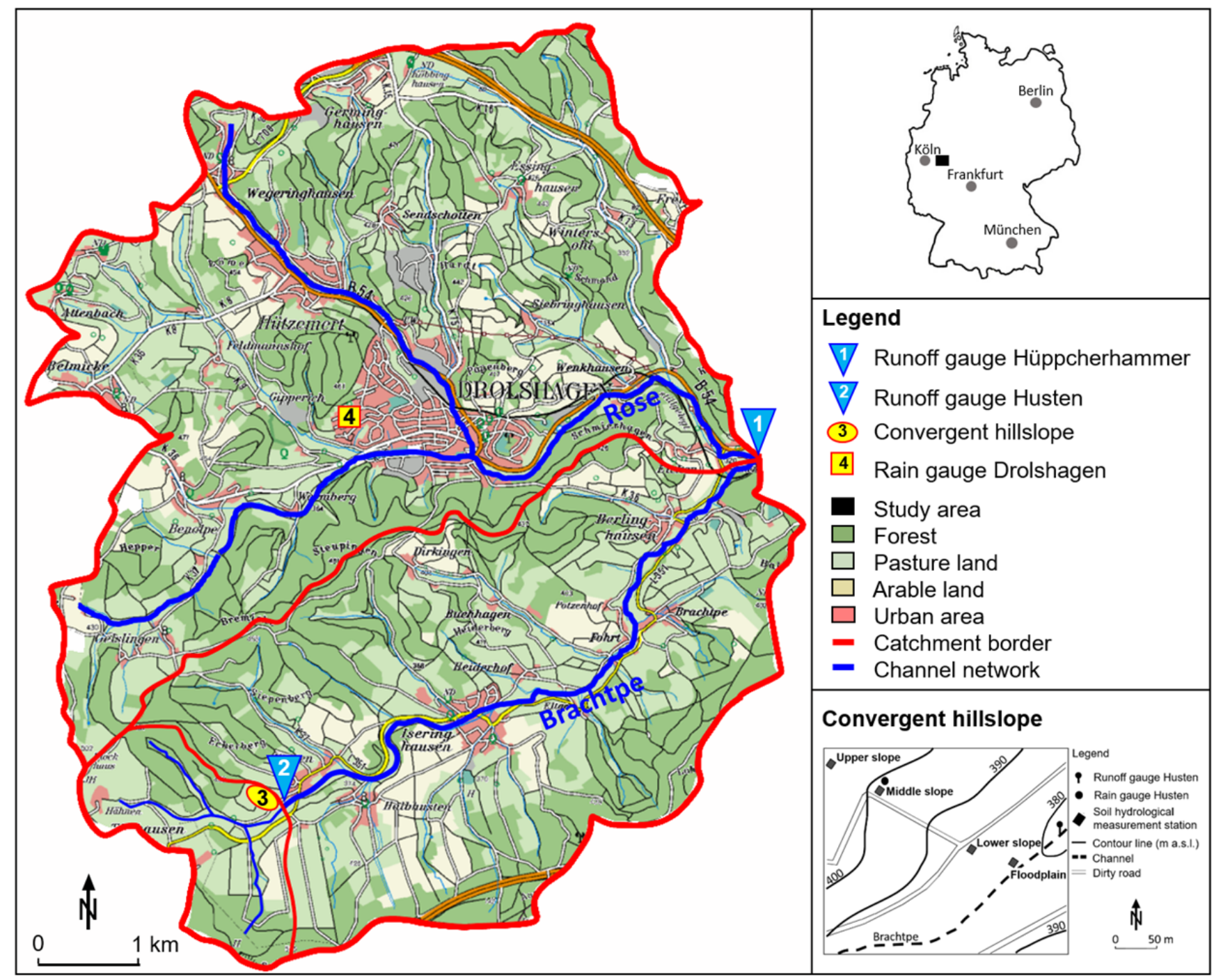

Fig. 1. Nested catchments Husten and Hüppcherhammer with locations of gauging, meteorological and soil moisture stations. (Base map: Bezirksregierung Köln, 2015).

slope deposits complemented by Leptosols and Stagnosols are the most prominent soils in the catchment (Chifflard et al., 2008).

\section{METHODS}

\section{Measurements}

Rainfall was measured in the small catchment Husten using a tipping bucket and recorded every 10 minutes (Fig. 1). Additionally, information on rainfall in the meso-scale catchment was supplemented by daily rainfall data from Drolshagen where no further temporal resolution is available. Snowfall and periods with snow cover are excluded from the data set. These periods were determined by using the meteorological dataset of the station Drolshagen where information about the daily snow depth are available.

Water level at the gauging stations Hüppcherhammer (15 min-interval) and Husten (10 min-interval) was observed by a bubble gauge and an $\mathrm{H}$-flume, respectively. Discharge was calculated by the application of a water level-discharge relationship.

To monitor the soil moisture status, a convergent hillslope under grass cover $\left(70 \mathrm{~m}\right.$ in height, inclination of $8^{\circ}$ and a mean altitude of $411 \mathrm{~m}$ a.s.1.) was equipped with tensiometers in 2 replicates per depth $(20 \mathrm{~cm}$ up to $200 \mathrm{~cm})$ following a hypothe- sized moisture gradient from upper slope to lower slope (for position and denomination of the tensiometer station cf. Fig. 1). The lowermost tensiometers were installed in floodplain sediments frequently saturated by groundwater from the nearby Brachtpe creek. Soil moisture was measured with pressuretransducer tensiometers, retrieved and logged every 10 minutes. The measurement unit was hPa. High positive values stand for dry soils, negative values stand for saturation below the groundwater or stagnant water table. Compared to measurement techniques for soil water content, tensiometers provide the advantage that they allow the hydraulic pressure within the aquifer to be quantified as well.

The following measurement depths for the soil water potential (S) are available at the different plots. The second letter in the abbreviation designates the slope position and the subscript stands for depth in $\mathrm{cm}$ :

Floodplain $\quad \mathrm{SF}_{20}, \mathrm{SF}_{50}, \mathrm{SF}_{80}, \mathrm{SF}_{120}, \mathrm{SF}_{150}$

Lower slope $\mathrm{SL}_{20}, \mathrm{SL}_{50}, \mathrm{SL}_{80}, \mathrm{SL}_{120}, \mathrm{SL}_{150}, \mathrm{SL}_{190}$

Middle slope $\mathrm{SM}_{20}, \mathrm{SM}_{50}, \mathrm{SM}_{80}, \mathrm{SM}_{120}, \mathrm{SM}_{150}, \mathrm{SM}_{180}, \mathrm{SM}_{200}$

Unper slope $\mathrm{SU}_{20}, \mathrm{SU}_{50}, \mathrm{SU}_{80}, \mathrm{SU}_{120}$

For the further study the dataset from 2002 till 2003 was used. The observation period of the different variables (rainfall, 
runoff, soil water potential) extends over the duration of about 10 years starting in 1999.

\section{Definition and delineation of rainfall and discharge events}

We used a pragmatic delineation to define single rainfall events, such as those introduced by Dikau (1986) and Baade (1994). According to our definition, a rainfall event starts with the first recording period and has ended when the following six hours stay dry. The additional rainfall data from Drolshagen was used to generate additional variables for the stepwise regression analysis. The primary purpose of this was to examine, if or how this additional information can improve the quality of the regression models. But the rainfall data from Drolshagen was not used for the assignment of rainfall and runoff events due to the daily sampling interval. The following variables attributed to each rainfall event:

$\left[\mathrm{P}_{\mathrm{t} 1}\right] \quad$ Rainfall $(\mathrm{mm})$ at catchment Husten

$\left[\mathrm{P}_{\mathrm{d}}\right]$ Duration of rainfall event (min) at catchment Husten

$\left[\mathrm{P}_{\text {int }}\right]$ Intensity of rainfall $(\mathrm{mm} / \mathrm{min})$ at catchment Husten

$\left[\mathrm{P}_{\text {int10 }}\right]$ Maximum 10 min-rainfall intensity at catchment Husten

$\left[\mathrm{P}_{\mathrm{t} 2}\right]$ Daily rainfall $(\mathrm{mm})$ at Drolshagen (meso-scale catchment)

$\left[\mathrm{P}_{\mathrm{t} 3}\right] \quad$ Daily rainfall $(\mathrm{mm})$ at catchment Husten

$[\Delta \mathrm{P}] \quad$ Absolute difference between $\left[\mathrm{P}_{\mathrm{t} 2}\right]$ and $\left[\mathrm{P}_{\mathrm{t} 3}\right]$

A discharge event starts once the discharge rate increases by $0.001 \mathrm{~m}^{3} / \mathrm{s}$. This threshold factors in the precision of the gauging station and excludes discharge fluctuations not caused by rainfall. A discharge event is considered over at the first interval in which the slope of the hydrograph falls below that of the dry weather base flow recession curve. The variable discharge volume summarizes all runoff components during an event including baseflow, surface and subsurface runoff. The following variables are attributed to each rainfall event:

$\left[\mathrm{Q}_{\mathrm{i}-1}\right]$ Discharge prior to the event (pre-event discharge) $\left[\mathrm{m}^{3} / \mathrm{s}\right]$

$\left[\mathrm{Q}_{\max }\right]$ Maximum discharge $\left[\mathrm{m}^{3} / \mathrm{s}\right]$ (peak flow)

$\left[\mathrm{Q}_{\mathrm{d}}\right]$ Duration of discharge event [min]

$\left[\mathrm{Q}_{\mathrm{V}}\right]$ Discharge volume $\left[\mathrm{m}^{3}\right]$

\section{Assigning discharge events to rainfall events}

Every runoff event measured at the gauging station Hüppcherhammer or Husten is assigned a triggering rainfall event identified at the meteorological station in the small catchment Husten (cf. Fig. 1). This event-based assignment is easily performed for the small catchment Husten, which is characterized by a short runoff response. This assignment is more complicated for the meso-scale catchment Hüppcherhammer due to its size, the distance between the meteorological station and the catchment outlet (about $9 \mathrm{~km}$ ) as well as the fact that the catchment mainly consists of two sub-basins.

To decide, if a runoff event identified at the gauging station Hüppcherhammer could have been triggered by a rainfall event measured at the meteorological station Husten, a specific maximum time interval was defined for every runoff event. This specific time interval represents the maximum possible duration between the end of a local rainfall event in Husten and the starting point of the resulting discharge increase at the gauging station Hüppcherhammer given the prevalent discharge conditions (Table 1). If the time difference between a discharge event and the previous rainfall event exceeds this time interval, another event must have triggered the discharge at the gauging station Hüppcherhammer. In this case, the discharge event is discarded. Those discharge events could result from faulty rainfall measurement or rainfall events restricted to the subbasin of the Rose creek. Furthermore, increased discharge could be the result of anthropogenic influence due to the village Drolshagen and the industry located there. The intervals are derived from flow velocity data measured by Schendzielorz (2004) on the $9 \mathrm{~km}$ stretch between the gauging station Hüppcherhammer and Husten. This data was linked to discharge classes that cover the span of the mean discharge of all runoff events at the gauging station Hüppcherhammer (Table 1). In the event a specific discharge event covers several rainfall events, these rainfall events will be connected and attributed to the first triggering rainfall event.

Table 1. Assignment of rainfall and runoff events on the basis of mean discharge of a runoff event.

\begin{tabular}{|c|c|c|c|}
\hline Category & $\begin{array}{c}\text { Upper limit of } \\
\text { mean discharge } \\
{\left[\mathrm{m}^{3} / \mathrm{s}\right] \text { of the }} \\
\text { runoff event }\end{array}$ & $\begin{array}{c}\text { Lower limit } \\
\text { of velocity } \\
{[\mathrm{m} / \mathrm{s}]}\end{array}$ & $\begin{array}{c}\text { Upper limit of } \\
\text { duration for the } \\
\text { assignment }[\mathrm{min}]\end{array}$ \\
\hline 1 & 2.43 & 0.045 & 2741 \\
\hline 2 & 4.83 & 0.282 & 438 \\
\hline 3 & 7.24 & 0.518 & 238 \\
\hline 4 & 9.65 & 0.755 & 163 \\
\hline 5 & 12.06 & 0.991 & 124 \\
\hline
\end{tabular}

\section{Antecedent soil moisture}

Antecedent soil moisture at $20 \mathrm{~cm}$ depth at all stations $\left(\mathrm{SF}_{20}\right.$, $\mathrm{SL}_{20}, \mathrm{SM}_{20}, \mathrm{SU}_{20}$ ) measured 10 minutes before the onset of rainfall is assigned to the combined rainfall-runoff-event.

\section{Statistics}

As the multicollinearity of predictor variables can be problematic (Hedderich and Sachs, 2016), the variance inflation factor (VIF) of all potential predictors was calculated (Table 2). Since only the variable $\mathrm{SL}_{80}$ and $\mathrm{SL}_{120}$ show a VIF of about 25 due to a high correlation coefficient of 0.98 , these parameters where separated and assigned into different subsets, one including $\mathrm{SL}_{80}$ and one including $\mathrm{SL}_{120}$. Stepwise regression analyses were based on the latter subset and performed using SPSS Software Package, Version 17. The analyses included $\left[\mathrm{Q}_{\max }\right]$, $\left[\mathrm{Q}_{\mathrm{d}}\right],\left[\mathrm{Q}_{\mathrm{V}}\right]$ as dependent variables and $\left[\mathrm{P}_{\mathrm{t} 1}\right],\left[\mathrm{P}_{\mathrm{t} 2}\right],\left[\mathrm{P}_{\mathrm{d}}\right],\left[\mathrm{P}_{\mathrm{int}}\right]$, $\left[\mathrm{P}_{\text {int10 }}\right],\left[\mathrm{Q}_{\mathrm{i}-1}\right],[\Delta \mathrm{P}]$ and $\mathrm{SF}$ (soil moisture floodplain), SL (soil moisture lower slope), SM (soil moisture middle slope) SU (soil moisture upper slope) as independent variables. Independent variables are introduced one after another into the regression model, starting with variables that show the smallest F-probabilities. The software's default options were applied. The routine tracks the individual steps of the fitting procedures until the thresholds for inclusion and exclusion of variables are reached.

\section{RESULTS}

In the observation period (2002 and 2003) 30 events for the small-scale and 100 events for the meso-scale catchment were successfully isolated. Table 3 contains the main characteristics of the measured rainfall and runoff events in both catchments.

The majority $(\mathrm{n}=71)$ of the events measured at the gauging station Hüppcherhammer was recorded during the summer. The duration $\left(\mathrm{P}_{\mathrm{d}}\right)$ and the amount $\left(\mathrm{P}_{\mathrm{t}}\right)$ of the winter rainfall events are noticeably higher than of the summer events, whereas 
The significance of soil moisture in forecasting characteristics of flood events. A statistical analysis in two nested catchments.

Table 2. Variance inflation factors (VIF) of all potential predictors.

$\begin{array}{lllllllllllllllllll} & \mathrm{P}_{\mathrm{t} 1} & \mathrm{Q}_{1.1} & \mathrm{P}_{\text {int }} & \mathrm{SF}_{20} & \mathrm{SF}_{50} & \mathrm{SF}_{80} & \mathrm{SF}_{120} & \mathrm{SF}_{150} & \mathrm{SL}_{20} & \mathrm{SL}_{50} & \mathrm{SL}_{80} & \mathrm{SL}_{120} & \mathrm{SL}_{150} & \mathrm{SL}_{200} & \mathrm{P}_{\mathrm{d}} & \mathrm{P}_{\text {int10 }} \\ \mathrm{P}_{\mathrm{t} 1} & & 1.16 & 1.03 & 1.00 & 1.00 & 1.00 & 1.00 & 1.00 & 1.01 & 1.03 & 1.03 & 1.02 & 1.00 & 1.01 & 2.58 & 1.12 \\ \mathrm{Q}_{1.1} & 1.16 & & 1.01 & 1.04 & 1.24 & 1.30 & 1.37 & 1.41 & 1.02 & 1.01 & 1.02 & 1.02 & 1.07 & 1.18 & 1.12 & 1.00 \\ \mathrm{P}_{\text {int }} & 1.03 & 1.01 & & 1.02 & 1.03 & 1.04 & 1.02 & 1.04 & 1.00 & 1.02 & 1.03 & 1.03 & 1.03 & 1.00 & 1.07 & 1.38 \\ \mathrm{SF}_{20} & 1.00 & 1.04 & 1.02 & & 3.85 & 1.67 & 2.16 & 2.03 & 2.01 & 1.68 & 2.05 & 1.96 & 1.16 & 1.10 & 1.01 & 1.02 \\ \mathrm{SF}_{50} & 1.00 & 1.24 & 1.03 & 3.85 & & 3.92 & 6.96 & 8.11 & 1.88 & 1.55 & 1.81 & 1.80 & 1.20 & 1.32 & 1.02 & 1.06 \\ \mathrm{SF}_{80} & 1.00 & 1.30 & 1.04 & 1.67 & 3.92 & & 2.52 & 5.49 & 1.47 & 1.23 & 1.28 & 1.34 & 1.13 & 1.28 & 1.04 & 1.11 \\ \mathrm{SF}_{120} & 1.00 & 1.37 & 1.02 & 2.16 & 6.96 & 2.52 & & 7.36 & 1.55 & 1.39 & 1.56 & 1.52 & 1.22 & 1.34 & 1.02 & 1.04 \\ \mathrm{SF}_{150} & 1.00 & 1.41 & 1.04 & 2.03 & 8.11 & 5.49 & 7.36 & & 1.57 & 1.34 & 1.47 & 1.49 & 1.19 & 1.36 & 1.03 & 1.12 \\ \mathrm{SL}_{20} & 1.01 & 1.02 & 1.00 & 2.01 & 1.88 & 1.47 & 1.55 & 1.57 & & 2.62 & 1.75 & 1.62 & 1.05 & 1.04 & 1.00 & 1.00 \\ \mathrm{SL}_{50} & 1.03 & 1.01 & 1.02 & 1.68 & 1.55 & 1.23 & 1.39 & 1.34 & 2.62 & & 5.67 & 5.14 & 1.46 & 1.10 & 1.00 & 1.00 \\ \mathrm{SL}_{80} & 1.03 & 1.02 & 1.03 & 2.05 & 1.81 & 1.28 & 1.56 & 1.47 & 1.75 & 5.67 & & 25.71 & 1.68 & 1.15 & 1.00 & 1.01 \\ \mathrm{SL}_{120} & 1.02 & 1.02 & 1.03 & 1.96 & 1.80 & 1.34 & 1.52 & 1.49 & 1.62 & 5.14 & 25.71 & & 2.01 & 1.21 & 1.00 & 1.01 \\ \mathrm{SL}_{150} & 1.00 & 1.07 & 1.03 & 1.16 & 1.20 & 1.13 & 1.22 & 1.19 & 1.05 & 1.46 & 1.68 & 2.01 & & 1.90 & 1.03 & 1.00 \\ \mathrm{SL}_{200} & 1.01 & 1.18 & 1.00 & 1.10 & 1.32 & 1.28 & 1.34 & 1.36 & 1.04 & 1.10 & 1.15 & 1.21 & 1.90 & & 1.03 & 1.01 \\ \mathrm{P}_{\mathrm{d}} & 2.58 & 1.12 & 1.07 & 1.01 & 1.02 & 1.04 & 1.02 & 1.03 & 1.00 & 1.00 & 1.00 & 1.00 & 1.03 & 1.03 & & 1.00 \\ \mathrm{P}_{\text {int10 }} & 1.12 & 1.00 & 1.38 & 1.02 & 1.06 & 1.11 & 1.04 & 1.12 & 1.00 & 1.00 & 1.01 & 1.01 & 1.00 & 1.01 & 1.00 & \end{array}$

Table 3. Characteristics of the rainfall and discharge events in the catchments Husten and Hüppcherhammer.

\begin{tabular}{|c|c|c|c|c|}
\hline & \multicolumn{2}{|c|}{ Hüppcherhammer } & \multicolumn{2}{|c|}{ Husten } \\
\hline & $\begin{array}{l}\text { Winter: } \\
\text { Average; } \min \text { - max }\end{array}$ & $\begin{array}{l}\text { Summer: } \\
\text { Average; } \min -\max \end{array}$ & $\begin{array}{l}\text { Winter: } \\
\text { Average; } \min -\max \end{array}$ & $\begin{array}{l}\text { Summer: } \\
\text { Average; } \min -\max \end{array}$ \\
\hline$\left[\mathrm{Q}_{\mathrm{i}-1}\right]$ & $0.95 \mathrm{~m}^{3} / \mathrm{s} ; 0.17-6.73 \mathrm{~m}^{3} / \mathrm{s}$ & $0.35 \mathrm{~m}^{3} / \mathrm{s} ; 0.10-1.34 \mathrm{~m}^{3} / \mathrm{s}$ & $0.09 \mathrm{~m}^{3} / \mathrm{s} ; 0.01-0.31 \mathrm{~m}^{3} / \mathrm{s}$ & $0.02 \mathrm{~m}^{3} / \mathrm{s} ; 0.01-0.09 \mathrm{~m}^{3} / \mathrm{s}$ \\
\hline$\left[\mathrm{Q}_{\max }\right]$ & $13.7 \mathrm{~m}^{3} / \mathrm{s}$ & $1.19 \mathrm{~m}^{3} / \mathrm{s}$ & $0.2 \mathrm{~m}^{3} / \mathrm{s} ; 0.02-0.69 \mathrm{~m}^{3} / \mathrm{s}$ & $0.07 \mathrm{~m}^{3} / \mathrm{s} ; 0.01-0.32 \mathrm{~m}^{3} / \mathrm{s}$ \\
\hline$\left[\mathrm{Q}_{\mathrm{d}}\right]$ & $1,902 \mathrm{~min} ; 45-6,825 \mathrm{~min}$ & $1,272 \mathrm{~min} ; 15-11,490 \mathrm{~min}$ & $597 \mathrm{~min} ; 120-1,290 \mathrm{~min}$ & $721 \mathrm{~min} ; 405-1,500 \mathrm{~min}$ \\
\hline$\left[\mathrm{Q}_{\mathrm{V}}\right]$ & $245,000 \mathrm{~m}^{3} ; 2,365-3,374,300 \mathrm{~m}^{3}$ & $82,900 \mathrm{~m}^{3} ; 224-2,542,400 \mathrm{~min}$ & $5,936 \mathrm{~m}^{3} ; 212-22,378 \mathrm{~m}^{3}$ & $2,115 \mathrm{~m}^{3} ; 297-8,651 \mathrm{~m}^{3}$ \\
\hline$\left[\mathrm{P}_{\mathrm{t} 1}\right]$ & & & $14.1 \mathrm{~mm} ; 0.2-66 \mathrm{~mm}$ & $10.7 \mathrm{~mm} ; 0.2-79.4 \mathrm{~mm}$ \\
\hline$\left[\mathrm{P}_{\mathrm{d}}\right]$ & & & $1,196 \mathrm{~min} ; 10-3,890 \mathrm{~min}$ & $675 \mathrm{~min} ; 10-5,000 \mathrm{~min}$ \\
\hline$\left[\mathrm{P}_{\text {int }}\right]$ & & & $\begin{array}{l}0.014 \mathrm{~mm} / \mathrm{min} ; \\
0.004-0.067 \mathrm{~mm} / \mathrm{min}\end{array}$ & $\begin{array}{l}0.023 \mathrm{~mm} / \mathrm{min} ; \\
0.001-0.093 \mathrm{~mm} / \mathrm{min}\end{array}$ \\
\hline$\left[\mathrm{P}_{\text {int10 }}\right]$ & & & $\begin{array}{l}1.3 \mathrm{~mm} / 10 \mathrm{~min} \\
0.2-3.8 \mathrm{~mm} / 10 \mathrm{~min}\end{array}$ & $\begin{array}{l}1.7 \mathrm{~mm} / 10 \mathrm{~min} ; \\
0.2-6.4 \mathrm{~mm} / 10 \mathrm{~min}\end{array}$ \\
\hline$\left[\mathrm{P}_{\mathrm{t} 2}\right]$ & $14.9 \mathrm{~mm} / \mathrm{d} ; 0-76.8 \mathrm{~mm} / \mathrm{d}$ & $10.8 \mathrm{~mm} / \mathrm{d} ; 0-75.2 \mathrm{~mm} / \mathrm{d}$ & & \\
\hline$\left[\mathrm{P}_{\mathrm{t} 3}\right]$ & & & $14.3 \mathrm{~mm} / \mathrm{d} ; 0-72.6 \mathrm{~mm} / \mathrm{d}$ & $11.2 \mathrm{~mm} / \mathrm{d} ; 0-79.8 \mathrm{~mm} / \mathrm{d}$ \\
\hline MQ & \multicolumn{2}{|c|}{$1.24 \mathrm{~m}^{3} / \mathrm{s}$ (48 years) } & \multicolumn{2}{|c|}{$0.078 \mathrm{~m}^{3} / \mathrm{s}(8$ years $)$} \\
\hline $\mathrm{HQ}$ & \multicolumn{2}{|c|}{$37.3 \mathrm{~m}^{3} / \mathrm{s}$ (48 years) } & \multicolumn{2}{|c|}{$3.16 \mathrm{~m}^{3} / \mathrm{s}(8$ years $)$} \\
\hline
\end{tabular}

the rainfall intensity $\left(\mathrm{P}_{\text {int }}\right)$ of the events in summer is higher than in winter (Table 3). Spatially, merely a small difference was detected in daily rainfall measured at the station Drolshagen $\left(\mathrm{P}_{\mathrm{t} 2}\right)$ and Husten $\left(\mathrm{P}_{\mathrm{t} 3}\right)$ during summer and winter. At the gauging station Hüppcherhammer, the duration of the runoff events $\left(Q_{d}\right)$ is, on average, 1902 minutes during the summer and 1272 minute during the winter. Also the total runoff amount (Qv) of an event is higher in winter (Ø $\left.245.000 \mathrm{~m}^{3}\right)$ than in the summer $\left(\varnothing 82.900 \mathrm{~m}^{3}\right)$. The pre-event discharge $\left(\mathrm{Q}_{\mathrm{i}-1}\right)$ is lower in summer $\left(0.35 \mathrm{~m}^{3} / \mathrm{s}\right)$ than in winter $\left(0.95 \mathrm{~m}^{3} / \mathrm{s}\right)$.

\section{Relations between soil water potential and discharge in the catchment Husten}

The relationship between soil water potential (SF, SL, SM, $\mathrm{SU})$ and discharge in the small-scale catchment Husten for the observation period 2001 underlines the influence of wetness conditions on discharge (Fig. 2). The scattering of the soil water tensions and the discharge values based on a 30 min-interval clearly shows that runoff increases if and only if the soil water potential in the upper soil $(20 \mathrm{~cm})$ reaches a specific threshold $(60 \mathrm{hPa})$ which is similar to the upper, middle and lower slope. The threshold at the floodplain position is approximately $0 \mathrm{hPa}$. These thresholds describe the alternation between unsaturated and saturated conditions, which are combined with different flow velocities of the subsurface soil water and impacted by topographic features. Thus, for a higher discharge both the saturation of the upper and the lower soil is necessary. Additionally, the locations upper (SU), middle slope (SM) and lower slope (SL) show a similar scattering of the measured soil water potential and similar thresholds, which indicates that these two locations are characterized by a comparable soil hydrological behavior. Thus, these locations can be described as a hillslope hydrological system in comparison to the location at the floodplain (SF) which represents the riparian zone.

\section{Regression model for the small-scale catchment Husten}

In 2002 and 2003, 30 events could be isolated for the smallscale catchment. Due to the limited number of observations, separate calculations and statistical analyses were not performed for winter and summer seasons. The regression models show that, besides rainfall, soil water potential at the lower slope $\left(\mathrm{SL}_{200}\right)$ and floodplain $\left(\mathrm{SF}_{20}, \mathrm{SF}_{80}\right)$ sites are highly relevant for peak discharge and discharge volume (Tables 4 and 5).

In the floodplain, soil moisture in the topsoil $(20 \mathrm{~cm})$ was detected as a significant variable for peak discharge, and soil moisture in the subsoil $(80 \mathrm{~cm})$ of the lower slope is part of the regression for discharge volume. Total rainfall is also significant for peak discharge and discharge volume in the models. 

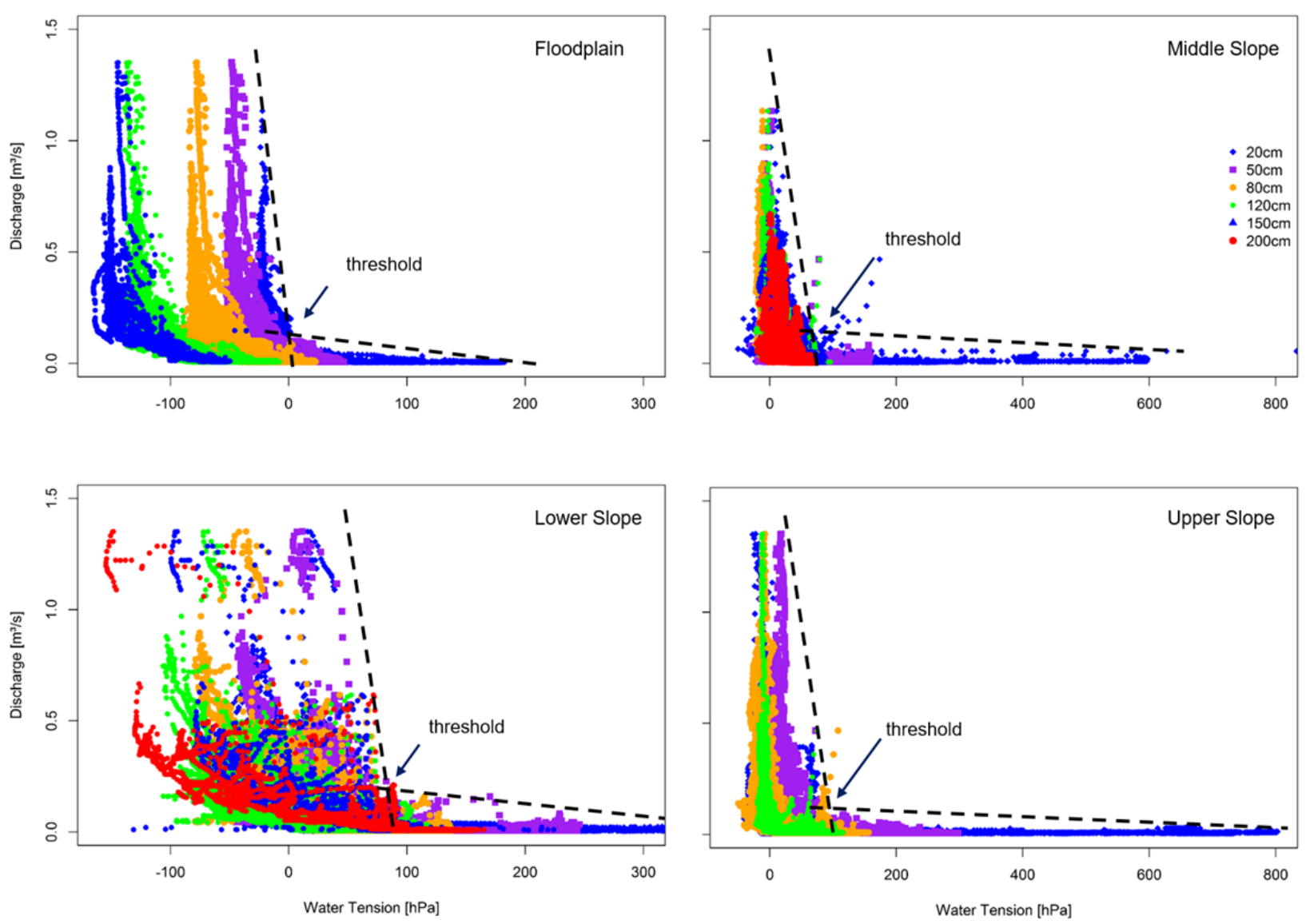

Fig. 2. Relationship between soil water potential at SF, SL, SM, SU and discharge in the catchment Husten for 2001 (30 min-interval; crossing points of the dashed lines indicate the thresholds).

Discharge duration, however, cannot be explained by any combination of variables in the catchment Husten. Only the soil water potential at the lower slope $\left(\mathrm{SL}_{200}\right)$ can explain about $14 \%$ of the scattering. Soil moisture of the middle and upper slope sites are not included in the regression model, which indicates that during the hydrological conditions of the observation period these sites are not sensitive for the prediction of peak discharge and discharge volume in the small catchment Husten. On the whole, the adding of the soil moisture potential from the flood plain and the lower slope improves considerably the quality of the regression models for the target variables peak discharge, discharge duration and discharge volume by approximately $10 \%, 14 \%$ and $21 \%$ at the small-scale catchment.

\section{Results for the meso-scale catchment Hüppcherhammer}

For 2002 and 2003, 100 events could be isolated for the meso-scale catchment Hüppcherhammer. Due to the large number of observations, separate calculations and statistical analyses for the hydrological winter and summer seasons could be performed. The regression models show that different independent variables are necessary for the prediction of the different discharge variables during the winter and summer seasons (Table 6 and 7). Additionally, the characteristics of rainfall events and soil moisture often show greater spatiotemporal variance during summer. Thus, more variables are stepwise included in the model to depict the more complex situation. Comparing the coefficients of determination of the different regression models it is noteworthy that the coefficients for the winter are nearly always higher than for the summer or for both periods combined. On the whole, for the different target variables peak discharge, discharge duration and discharge volume the adding of the soil moisture from the flood plain and the lower slope as explanatory variable improves the quality of the regression model for the meso-scale catchment by $15 \%, 20 \%$ and $10 \%$, respectively, especially during the summer season. In the winter season the improvement is smaller (up to 6\%) and the regression models mainly include rainfall characteristics as explanatory variables.

The most important explanatory variables for peak flow $\left(\mathrm{Q}_{\max }\right)$ are rainfall variables (Table 7); this is daily rainfall in winter and event rainfall in summer. The different rainfall variables can be interpreted as to the dominance of short and localized rain storms during summer, whereas more evenly distributed rainfall is common in winter. Aside from rainfall, the pre-event discharge is significant for the peak discharge in winter.

Soil moisture at a depth of $50 \mathrm{~cm}$ at the floodplain site increases the model quality for both the total period and for the summer.

Unsurprisingly, rainfall duration best explains the duration of a discharge $\left(Q_{d}\right)$ event, particularly in winter, when soil moisture is less variable (Table 8). Aside from rainfall duration, maximum 10-minute rainfall intensity is the sole additional variable in the final model for the winter season. Soil moisture at the lower slope position increases the quality of the model for the summer. In the stepwise search for the variables that

Table 4. Small-scale catchment Husten: Coefficient of determination of the regression models and independent variables with algebraic sign.

\begin{tabular}{|l|l|}
\hline & Husten, all events $(\mathrm{n}=30)$ \\
\hline$\left[\mathrm{Q}_{\max }\right]$ & $0.777\left(\left[+\mathrm{P}_{\mathrm{t} 1}\right],\left[-\mathrm{SF}_{20}\right]\right)$ \\
\hline$\left[\mathrm{Q}_{\mathrm{d}}\right]$ & $0.144\left(\left[-\mathrm{SL}_{200}\right]\right)$ \\
\hline$\left[\mathrm{Q}_{\mathrm{V}}\right]$ & $0.892\left(\left[+\mathrm{P}_{\mathrm{t}}\right],\left[-\mathrm{SF}_{80}\right]\right)$ \\
\hline
\end{tabular}


The significance of soil moisture in forecasting characteristics of flood events. A statistical analysis in two nested catchments.

Table 5. Stepwise regression analyses for $\mathrm{Q}_{\max } \mathrm{Q}_{\mathrm{d}}$ and $\mathrm{Q}_{\mathrm{v}}$ with the coefficients of determination (Husten).

\begin{tabular}{|c|c|c|c|c|c|c|c|c|c|c|c|c|c|c|c|c|c|c|}
\hline & $\mathbf{Q}_{\max }$ & & & $Q_{d}$ & & $Q_{v}$ & & & & & & & dj. $R$ & & & & & \\
\hline $\begin{array}{l}\text { Model } \\
\text { no. }\end{array}$ & adj. $R^{2}$ & $P_{11}$ & $\mathrm{SF}_{30}$ & adj. $R^{2}$ & $\mathrm{SL}_{200}$ & adi. $R^{2}$ & $P_{.}$ & $\mathrm{SF}_{80}$ & 0.1 & 0.2 & 0.3 & 0.4 & 0.5 & 0.6 & 0.7 & 0.8 & 0.9 & 1 \\
\hline 1 & 0.686 & $x$ & & 0.144 & $x$ & 0.682 & $x$ & & 0 & & & & & & 0 & & & \\
\hline 2 & 0.777 & $\mathrm{x}$ & $x$ & & & 0.892 & $x$ & $x$ & & & & & & & & 0 & C & \\
\hline
\end{tabular}

$=Q_{\max } ;=Q_{\mathrm{d}} ;=Q_{\mathrm{v}}$

Table 6. Meso-scale catchment Hüppcherhammer: Coefficient of determination of the regression models and independent variables with algebraic sign.

\begin{tabular}{|l|l|l|l|}
\hline & All events $(\mathrm{n}=100)$ & Winter events $(\mathrm{n}=29)$ & Summer events $(\mathrm{n}=71)$ \\
\hline$\left[\mathrm{Q}_{\max }\right]$ & $0.833\left(\left[+\mathrm{P}_{\mathrm{t} 1}\right],\left[+\mathrm{Q}_{\mathrm{i}-1}\right],\left[+\mathrm{P}_{\mathrm{d}}\right],\left[-\mathrm{SF}_{50}\right],\left[+\mathrm{P}_{\mathrm{t} 2}\right]\right)$ & $0.920\left(\left[+\mathrm{P}_{\mathrm{t} 2}\right],\left[+\mathrm{Q}_{\mathrm{i}-1}\right]\right.$ & $0.762\left(\left[\mathrm{P}_{\mathrm{t} 1}\right],\left[-\mathrm{SF}_{50}\right],\left[+\mathrm{P}_{\mathrm{d}}\right],[-\Delta \mathrm{P}]\right)$ \\
\hline$\left[\mathrm{Q}_{\mathrm{d}}\right]$ & $0.672\left(\left[+\mathrm{P}_{\mathrm{d}}\right],\left[-\mathrm{SL}_{120}\right],\left[+\mathrm{P}_{\mathrm{int}}\right],\left[-\mathrm{P}_{\mathrm{t} 2}\right],\left[+\mathrm{P}_{\mathrm{t} 1}\right]\right)$ & $0.791\left(\left[+\mathrm{P}_{\mathrm{d}}\right],\left[-\mathrm{P}_{\mathrm{int10}}\right]\right)$ & $0.711\left(\left[+\mathrm{P}_{\mathrm{d}}\right],\left[+\mathrm{P}_{\mathrm{t}}\right],\left[-\mathrm{SL}_{120}\right],\left[-\mathrm{P}_{\mathrm{t}}\right]\right.$, \\
& & & $\left.\left.\left[-\mathrm{SF}_{150}\right],\left[-\mathrm{SF}_{120}\right],\left[+\mathrm{P}_{\mathrm{int}}\right],\right],[-\Delta]\right)$ \\
\hline$\left[\mathrm{Q}_{\mathrm{v}}\right]$ & $0.819\left(\left[+\mathrm{Q}_{\mathrm{i}-1}\right],\left[+\mathrm{P}_{\mathrm{t} 1}\right],\left[-\mathrm{SL}_{120}\right],\left[-\mathrm{SF}_{120}\right],\left[-\mathrm{P}_{\mathrm{int} 10}\right]\right)$ & $0.925\left(\left[+\mathrm{Q}_{\mathrm{i}-1}\right],\left[+\mathrm{SF}_{120}\right],\left[+\mathrm{P}_{\mathrm{d}}\right]\right)$ & $\left.0.659\left(\left[+\mathrm{P}_{\mathrm{t} 1}\right],\left[-\mathrm{SL}_{120}\right],\right],\left[-\mathrm{P}_{\mathrm{int10}}\right]\right)$ \\
\hline
\end{tabular}

Table 7. Stepwise regression analyses for $\mathrm{Q}_{\max }$ with the coefficients of determination (Hüppcherhammer).

\begin{tabular}{|c|c|c|c|c|c|c|c|c|c|c|c|c|c|c|c|c|c|c|c|c|c|}
\hline \multirow{2}{*}{$\begin{array}{l}\text { Mod- } \\
\text { el } \\
\text { no. }\end{array}$} & \multicolumn{3}{|c|}{ adjusted $\mathrm{R}^{2}$} & \multirow{2}{*}{\multicolumn{2}{|c|}{$P_{t 1}$}} & \multirow{2}{*}{\multicolumn{2}{|c|}{$P_{d}$}} & \multirow{2}{*}{\multicolumn{2}{|c|}{$\mathrm{P}_{\mathrm{t} 2}$}} & \multirow[b]{2}{*}{$\Delta \mathrm{P}$} & \multirow{2}{*}{\multicolumn{2}{|c|}{$Q_{i-1}$}} & \multirow{2}{*}{\multicolumn{2}{|c|}{$\mathrm{SF}_{50}$}} & \multicolumn{7}{|c|}{ adjusted $R^{2}$} \\
\hline & $\bullet$ & 口 & $\Delta$ & & & & & & & & & & & & 0.5 & 0.6 & 0 . & 0 & 8 & 0.9 & 1 \\
\hline 1 & 0.641 & 0.612 & 0.823 & $\bullet$ & $\square$ & & & & $\Delta$ & & & & & & & $<$ & & & $\Delta$ & & \\
\hline 2 & 0.794 & 0.673 & 0.920 & $\bullet$ & a & & & & $\Delta$ & & $\bullet$ & $\Delta$ & & $\square$ & & & $\square$ & & 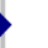 & $\Delta$ & \\
\hline 3 & 0.813 & 0.729 & & $\bullet$ & 口 & 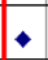 & 口 & & & & $\bullet$ & & & 口 & & & & $\square$ & 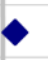 & & \\
\hline 4 & 0.823 & 0.762 & & $\bullet$ & 口 & 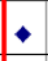 & ㅁ & & & 口 & $\bullet$ & & $\bullet$ & 口 & & & & 口 & 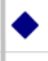 & & \\
\hline 5 & 0.833 & & & $\bullet$ & & 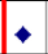 & & $\bullet$ & & & $\bullet$ & & $\bullet$ & & & & & & $\bullet$ & & \\
\hline
\end{tabular}

= 12-month period; $\mathbf{\square}=$ summer season (May 1 - October 31); $\mathbf{A}=$ winter season (November 1 - April 30)

Table 8. Stepwise regression analyses for $\mathrm{Q}_{\mathrm{d}}$ with the coefficients of determination (Hüppcherhammer).

\begin{tabular}{|c|c|c|c|c|c|c|c|c|c|c|c|c|c|c|c|c|}
\hline \multirow{2}{*}{\begin{tabular}{|l|} 
Mod- \\
el \\
no. \\
\end{tabular}} & \multicolumn{3}{|c|}{ adjusted $\mathrm{R}^{2}$} & \multirow[b]{2}{*}{$P_{t 1}$} & \multirow{2}{*}{\multicolumn{3}{|c|}{$P_{d}$}} & \multirow[b]{2}{*}{$P_{\text {int }}$} & \multirow[b]{2}{*}{$P_{\text {int10 }}$} & \multirow[b]{2}{*}{$\Delta \mathrm{P}$} & \multirow[b]{2}{*}{$P_{12}$} & \multirow[b]{2}{*}{$\mathrm{SF}_{120}$} & \multirow[b]{2}{*}{$\mathrm{SF}_{150}$} & \multirow[b]{2}{*}{$\mathrm{SL}_{20}$} & \multirow{2}{*}{\multicolumn{2}{|c|}{$\mathrm{SL}_{120}$}} \\
\hline & $\bullet$ & - & $\boldsymbol{\Delta}$ & & & & & & & & & & & & & \\
\hline 1 & 0.515 & 0.444 & 0.674 & & - & at & \begin{tabular}{|c|c|c|}
4 & 0
\end{tabular} & & & & & & & & & \\
\hline 2 & 0.559 & 0.509 & 0.791 & & . & $=$ & $\Delta$ & & $\Delta$ & & & & & = & . & \\
\hline 3 & 0.607 & 0.562 & & E & - & = & & • & & & & & & $\square$ & - & \\
\hline 4 & 0.620 & 0.598 & & 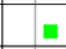 & 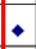 & 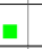 & & • & & & + & & & a & + & \\
\hline 5 & 0.672 & 0.596 & & - & - & 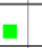 & & 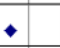 & & & 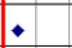 & & & & - & 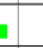 \\
\hline 6 & & 0.631 & & = & & 모․ & & & & & 口 & & & & s & 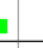 \\
\hline 7 & & 0.656 & & . & & a & & & & & $\square$ & & $\square$ & & 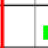 & 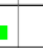 \\
\hline 8 & & 0.678 & & 물 & & 플 & & & & & $\square$ & a & 口 & & t & 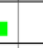 \\
\hline 9 & & 0.694 & & 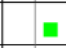 & & 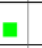 & & 口 & & & $\square$ & $\square$ & 口 & & 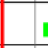 & 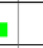 \\
\hline 10 & & 0.711 & & a & & a & & E & & E & $\square$ & $\square$ & $\square$ & & 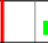 & 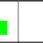 \\
\hline
\end{tabular}

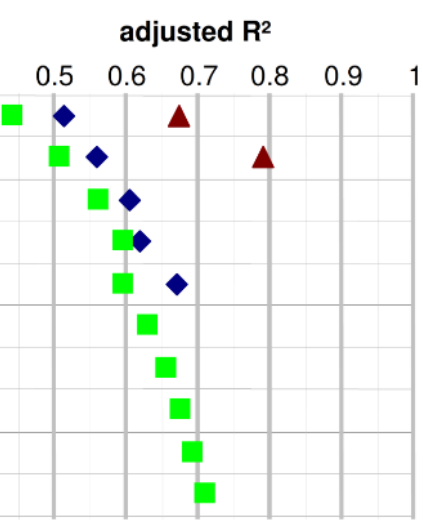

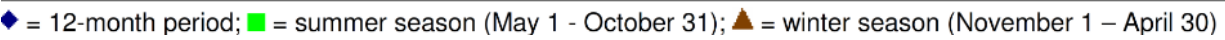

Table 9. Stepwise regression analyses for $\mathrm{Q}_{\mathrm{v}}$ with the coefficients of determination (Hüppcherhammer).

\begin{tabular}{|c|c|c|c|c|c|c|c|c|c|c|c|c|c|c|c|c|c|c|c|c|c|}
\hline \multirow{3}{*}{$\begin{array}{l}\text { Mod- } \\
\text { el } \\
\text { no. } \\
1\end{array}$} & \multicolumn{3}{|c|}{ adjusted $\mathrm{R}^{2}$} & \multirow{2}{*}{\multicolumn{2}{|c|}{$\mathrm{P}_{\mathrm{tI}}$}} & \multirow{2}{*}{\multicolumn{2}{|c|}{$\mathrm{P}_{\mathrm{d}}$}} & \multirow{2}{*}{\multicolumn{2}{|c|}{$P_{\text {int10 }}$}} & \multirow{2}{*}{\multicolumn{2}{|c|}{$Q_{i-1}$}} & \multirow{2}{*}{\multicolumn{2}{|c|}{$\mathrm{SF}_{120}$}} & \multirow{2}{*}{\multicolumn{2}{|c|}{$\mathrm{SL}_{120}$}} & \multicolumn{6}{|c|}{ adjusted $\mathbf{R}^{2}$} \\
\hline & $\bullet$ & $\square$ & $\mathbf{A}$ & & & & & & & & & & & & & 0.5 & 6 & 0.7 & 0.8 & & 9 \\
\hline & 0.557 & 0.543 & 0.801 & & घ & & & & & $\bullet$ & $\Delta$ & & & & & $\nabla$ & & & $\Delta$ & & \\
\hline 2 & 0.768 & 0.639 & 0.869 & $\bullet$ & 口 & & & & & $\bullet$ & $\Delta$ & & $\Delta$ & & 口 & & $\square$ & & $\diamond$ & $\Delta$ & \\
\hline 3 & 0.783 & 0.659 & 0.925 & $\bullet$ & - & & $\Delta$ & & 口 & $\bullet$ & $\Delta$ & & $\Delta$ & $\bullet$ & $\square$ & & $\square$ & & $\gamma$ & & $\Delta$ \\
\hline 4 & 0.809 & & & $\bullet$ & & & & & & $\bullet$ & & $\bullet$ & & $\bullet$ & & & & & 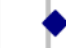 & & \\
\hline 5 & 0.819 & & & $\bullet$ & & & & $\bullet$ & & $\bullet$ & & $\bullet$ & & $\bullet$ & & & & & & & \\
\hline
\end{tabular}

$\checkmark=12-$ month period; $\square=$ summer season (May 1 - October 31); $\mathbf{A}=$ winter season (November 1 - April 30) 
best explain the variance, soil moisture at a depth of $20 \mathrm{~cm}$, introduced in step 2 , is replaced by soil moisture at a depth of $120 \mathrm{~cm}$ in step 5 . The daily rainfall measured at the additional gauging station $\left(\mathrm{P}_{\mathrm{t} 2}\right)$ in the meso-scale catchment is included in the models for the summer season and the 12-month period to depict the spatially more complex rainfall pattern in the summer. Furthermore, with the last step of the regression analysis the difference $(\Delta \mathrm{P})$ between the daily rainfall in Drolshagen $\left(\mathrm{P}_{\mathrm{t} 2}\right)$ and Husten $\left(\mathrm{P}_{\mathrm{t}}\right)$ becomes part of the final model for summer. Discharge prior to the event and the rainfall $\left[\mathrm{P}_{\mathrm{t} 1}\right]$ are by far the most important variables, resulting in a $\mathrm{R}^{2}$ of 0.768 (Table 9) for the total discharge volume $\left(\mathrm{Q}_{\mathrm{v}}\right)$ in the 12-month period. The addition of three more independent variables only slightly improves the quality of the model to 0.819 . During the winter period, the pre-event discharge appears to be most significant. This variable alone statistically explains $80 \%$ of the variance, however this high value is likely attributable to one extreme discharge event. Therefore, the hydrological relevance of the pre-event discharge must be discussed. Once again, soil moisture in $120 \mathrm{~cm}$ at the lower slope ranks second in importance behind rainfall in summer. Concerning flow volume in winter, soil moisture in the flood plain at a depth of $120 \mathrm{~cm}$ is more important than during summer, when soil moisture variability is high.

\section{DISCUSSION \\ Controlling factors for discharge at the small-scale catchment Husten}

At this spatial scale the results of the regression analyses clearly show that the event-based rainfall amount $\left(\mathrm{P}_{\mathrm{t} 1}\right)$ is the most important independent variable for predicting peak discharge and discharge volume, as it explains nearly $69 \%$ of their variability. The soil water potentials at depths of $20 \mathrm{~cm}$ and 80 $\mathrm{cm}\left(\mathrm{SF}_{20}\right.$ and $\left.\mathrm{SF}_{80}\right)$ at the floodplain site and of $200 \mathrm{~cm}$ at the lower slope site $\left(\mathrm{SL}_{200}\right)$ markedly improve the performance of these regression models up to coefficients of determination of 0.78 and 0.89 , respectively. For a small mountain catchment $\left(22 \mathrm{~km}^{2}\right)$ Kostka and Holko (2003) also showed that the runoff volume is mainly controlled by the rainfall amount. Nevertheless, the observation of the soil moisture dynamics at the point scale arranged at different slope positions (upper, middle, lower slope and floodplain) and covering different soil depths are a good estimator for the average soil moisture dynamics at the small-scale catchment. Furthermore, the inclusion of the variables $\mathrm{SF}_{20}, \mathrm{SF}_{80}$ and $\mathrm{SL}_{200}$ in the regression models indicates the importance that the adjacent floodplain and the lower hillslope wetness have for the runoff response in this small-scale catchment, especially for the prediction of the discharge volume (Qv). This is consistent with studies that show the wetness at the lower hillslope sector (Zehe et al., 2010) or the soil moisture at $30 \mathrm{~cm}$ soil depth (Aubert et al., 2003) has great explanatory power for event discharge. The pre-event discharge, which is often used for the antecedent wetness of a catchment (e.g. Graeff et al., 2009), has no statistical effect on the prediction of the mentioned runoff parameters in the small-scale catchment Husten. This underlines the importance of direct soil moisture measurements to estimate antecedent wetness as shown in e.g. Blume et al. (2009), Schädel (2006), Zehe and Blöschl (2004) or Zehe et al. (2010). Thus, a set of distributed point measurements of soil water potential may yield representative information on temporal soil moisture dynamics at the headwater scale. Additionally, this information on temporal soil water potential dynamics can be used and may even be advantageous for flood warning purposes, as shown by Aubert et al. (2003) and Anctil et al. (2008).

\section{Controlling factors for discharge at the meso-scale} catchment Hüppcherhammer

The results of the regression analyses show that the number of explanatory variables for the prediction of the runoff parameters (peak discharge, discharge volume and duration of discharge event) at the meso-scale catchment Hüppcherhammer $\left(47.2 \mathrm{~km}^{2}\right)$ are higher in the meso-scale catchment than in the small-scale catchment and additionally, are higher in summer than in winter. This indicates the greater complexity of the larger drainage basin. Small-scale temporal and spatial variability of processes that eventually generate creek and river discharge superimpose each other and smoothen the hydrograph. To achieve a reasonable statistical description for peak flow $\left(\mathrm{Q}_{\max }\right)$, at least one or more precipitation variables must be included in the model. One precipitation variable is sufficient for the winter model, whereas three precipitation variables are necessary to capture the effects of the temporally and spatially more complex precipitation situation in summer. For the latter, the combination of rainfall event sum and duration describe the rainfall intensity, which shows a much larger span in summer than in winter. To aid in describing the larger spatial variability of precipitation during summer, the difference in daily rainfall between the two measurement sites is included as a third precipitation variable as well. For both the summer and the total period, soil moisture at a depth of $50 \mathrm{~cm}$ at the floodplain site increases the model quality. Similar to the small-scale catchment and in accordance with the findings of Kostka and Holko (2003), this indicates the importance of the riparian zone in the headwater of a catchment in peak discharge prediction. Besides rainfall characteristics, the regression models for prediction of summer discharge duration also includes the lower slope soil moisture at a depth of $120 \mathrm{~cm}$, which depicts the connectivity between the slope hydrological system and the adjacent floodplain best. Blume and van Meerveld (2015) underline the importance of antecedent wetness conditions for the subsurface connectivity. In our study, the tensiometers were installed in the Sw-horizon of a soil with a transient perched aquifer that developed within the lower slope sediments. Thus, the water table gradient is steep and hydraulic conductivity is highest, which means a great deal of water is transferred towards the floodplain as subsurface runoff and eventually into the creek. Subsurface runoff is reported to be the dominant runoff process in many other studies of low mountain ranges in temperate climates (Bachmair and Weiler, 2011; Blume and van Meerveld, 2015; Moldenhauer et al., 2013). Indeed, the functional relationship to discharge is effective only when rainfall is incorporated in the model, but in this context the role of stratified soils has to be noticed. The soil moisture dynamic at the lower slope is influenced both by groundwater in the lower horizons $\left(\mathrm{SL}_{150}\right.$ $\left.\& \mathrm{SL}_{190}\right)$ and by soil water in the upper horizons $\left(\mathrm{SL}_{20} \& \mathrm{SL}_{50}\right)$. Thus, a high correlation of the temporal variability of the soil water measurements in these depths maybe expected, but the low VIF of these depths don `t confirm this assumption (Table 2). It is assumed, that the low VIF for the soil moisture variables are caused by the specific soil structure at this location, which is very heterogeneous. Stratified soils consist of different soil hydraulic properties in the different layers and horizons, which can cause different soil moisture dynamics within the same time period. Thus, the soil moisture dynamic on the different depths can be temporally decoupled more often than in homogenous soils and integrated separately into the developed regression models. The fact that during winter maximum 10-minute rainfall intensity is included as a second independent variable in the $\mathrm{Q}_{\mathrm{d}}$ model can be interpreted to represent the fast runoff 
The significance of soil moisture in forecasting characteristics of flood events. A statistical analysis in two nested catchments.

components. The variable has a negative coefficient, which means that especially high rainfall intensities are connected to relatively short events. The highly significant statistical relationship between pre-event discharge and flow volume $\left(\mathrm{Q}_{\mathrm{V}}\right)$ in winter was affected by a single, extreme event. If this is excluded from the dataset, $\mathrm{R}^{2}$ drops to 0.11 , whereas rainfall $\left[\mathrm{P}_{\mathrm{t} 1}\right]$ explains $38 \%$ of the variance. To conclude, the lower the base flow, the more important rainfall is for a high flow volume. This is in accordance with Zillgens et al. (2007), who analyzed 201 rainfall runoff events in three nested catchments $\left(0.07 \mathrm{~km}^{2}\right.$, $15.5 \mathrm{~km}^{2}$ and $150 \mathrm{~km}^{2}$; Saalach, Austrian Alps) and found that the characteristics of runoff events clearly depend on rainfall characteristics and initial base flow level.

In general, it has to be noticed that the adding of the soil water potential at the meso-scale catchment improves the predictive performance of the regression models relatively small by $15 \%$ (peak discharge), 20\% (discharge duration) and 10\% (discharge volume). This may be due to differences in hillslope geomorphology and correspondingly in soil hydrological responses to rainfall. Proceeding from the headwaters downstream, relatively large areas are more distant from the river and valley slopes steepen. This changes hydrological connectivity and soil hydrological reaction patterns. These effects might not have been covered by our experimental slope. Moreover, there is still a great need for research since the impact of the width of riparian areas on the hydrological subsurface connectivity between hillslope and stream is still not yet investigated sufficiently (Grabs et al., 2012; Jencso et al., 2010; Uchida et al., 2005). Especially for the shift from small-scale to mesoscale catchments the widths between hillslope and stream are increasing considerably. Additionally, the spatial variability of the rainfall within the meso-scale catchment could be a reason for the relatively small improvement of the regression models taking the soil water potential into account. However, the correlation of the daily rainfall of the station Drolshagen and Husten show a correlation coefficient of $r=0.95$ which underlines the assumption, that in this study the spatial variability of the rainfall events at the meso-scale catchment is negligible and emphasizes the importance of the hillslope geomorphology.

\section{Detecting the optimal placement of soil moisture sensors}

The significance of single point soil moisture measurements essentially depends on the identification of a suitable location due to a catchment's spatial heterogeneity. Here, the riparian zone and the lower hillslope locations (Kostka and Holko 2003; Zehe et al., 2010), which are included in nearly all regression models (except for $\mathrm{Q}_{\max }$ and $\mathrm{Q}_{\mathrm{d}}$ in winter) at both scales, play an important role. This indicates that the soil moisture measured at and near the base of a valley appears more important than the soil moisture conditions at the upper and the middle hillslope. This is consistent with results published by Sidle et al. (2000), McGlynn and McDonnell (2003), McGlynn and Seibert (2003) and Klaus et al. (2015), who also emphasize the importance of the riparian zone for the runoff response of a catchment. Woods et al. (1997) additionally indicate the relevance of riparian zones in the forefront of convergent hillslopes. Such topographic features foster the concentration of surface and subsurface runoff in the center of the hillslope and benefits saturated areas downwards as a result of lateral water flow and decreasing hillslope inclination. The soil moisture measurement sites lower hillslope (SL) and floodplain (SF) represent such areas forefront of convergent hillslopes and are included in regression models at both spatial scales. Thus, these findings suggest that convergent hillslopes are key landscape units for runoff generation in this catchment, which is typical for low mountain ranges in Central Europe. The single point measurement of the soil moisture in this functional unit and in the detected depths may be optimal for estimating the antecedent wetness of the small- and meso-scale catchments and may thus yield valuable information for flood warning.

\section{CONCLUSIONS}

The most important finding is that soil moisture appears significant in every regression model. The influence of soil moisture as a determinant is generally higher for summer events than in winter. Soil moisture, as an indicator of the catchment's wetness or sensitivity to generate discharge, modulates the discharge triggered by rainfall. The appearance of the soil moisture variables in the stepwise regression indicates their varying importance, depending on which characteristics of the discharge are of interest. Floodplain soil moisture is important in the models for flow volume (winter season) and peak flow (summer season) in both catchments. As the soil water potential from this site reflects the groundwater level, it not only represents the wetness caused by prior weather conditions (e.g. rainfall and evapotranspiration) but it also indicates the hydraulic status of the aquifer near the creek. Thus, it carries dual information and correlates with pre-event discharge.

On the other hand, soil moisture at the lower slope is of great significance for both flow volume and flow duration. Both models of the meso-scale catchment include the soil moisture at a depth of $120 \mathrm{~cm}$. As expected, lower slopes function as connective elements between the hydrological subsystem of the slope and that of the floodplain. Especially in the case of convergent slopes, subsurface flow is either quickly routed through the lower slope to the aquifer or it transmits a pressure pulse downslope towards the aquifer, where water eventually escapes to the receiving creeks. This is a strong argument for our hypothesis that using point data of soil moisture to forecast discharge characteristics for fairly large catchments is justified, as long as the measurement sites are carefully selected. Another prerequisite is that the entire moisture depth profile should be examined before defining the measurement depth with the highest significance.

Rainfall from two stations is incorporated in two of the three models for the meso-scale catchment. This is consistent with the practice (e.g. Pluntke et al., 2010) that spatial variations of precipitation cannot be neglected in scale transitions. In this respect, upscaling the most important input variable does not seem to be justified. We can assume that rainfall from the gauging station Drolshagen in the meso-scale catchment does not show up in the model for flow volume because it is substituted by the antecedent discharge which - standing alone or in combination with other variables - is indeed a highly significant determinant for peak flow and flow volume.

All in all, the number of independent variables is greater in the case of the meso-scale catchment than in the small scale catchment. For example, for $\mathrm{Q}_{\mathrm{D}}$ and $\mathrm{Q}_{\mathrm{V}}$ these are 5 and 2 variables, respectively. This reflects the greater complexity of the larger drainage basin, in which the runoff generating processes at the small scale are blurred. Small-scale spatiotemporal variability of processes that eventually generate creek and river discharge superimpose each other and smoothen the hydrograph. Consequently, characteristics of a discharge event cannot be assigned to data from single points that merely depict subordinate and local processes. We suspect that in general, discharge fluctuates considerably in small catchments, making flood forecasts extremely difficult at this scale. Also, the num- 
ber of explanatory variables is higher in summer (up to 10) than in winter ( 3 or less). This can be explained by the higher temporal and spatial variability of soil moisture in summer as well as the fact that localized rainfall events occur more often, many of which with high intensity.

Our study underpins the expedience of using tensiometers in place of TDR probes, which are commonly used (Brocca et al., 2007; Penna et al., 2011; Zehe et al., 2010) to assimilate soil moisture into rainfall-runoff modeling. Our analysis shows that further studies on flood forecasting should concentrate on carefully selecting representative measurement sites to improve the quality of forecasts instead of labor-intensive and costly attempts to monitor the soil moisture of an entire catchment. We value extensive soil moisture monitoring for its function in, for instance, precision farming and risk analysis concerning the fate of agrochemicals, however not in its use in operational flood warning systems.

\section{REFERENCES}

Ali, G., Tetzlaff, D., McDonnell, J.J., Soulsby, C., Carey, S., Laudon, H., McGuire, K., Buttle, J., Seibert, J., Shanley, J., 2015. Comparison of threshold hydrologic response across northern catchments. Hydrol. Process., 29, 16, 3575-3591.

Ali, G.A., Roy, A.G., Legendre, P., 2010. Spatial relationships between soil moisture patterns and topographic variables at multiple scales in a humid temperate forested catchment. Water Resour. Res., 46, W10526. DOI: 10.1029/2009wr008804.

Alvarez-Garreton, C., Ryu, D., Western, A.W., Crow, W.T., Robertson, D.E., 2014. The impacts of assimilating satellite soil moisture into a rainfall-runoff model in a semi-arid catchment. J. Hydrol., 519, 2763-2774.

Anctil, F., Lauzon, L., Filion, M., 2008. Added gains of soil moisture content observations for streamflow predictions using neural networks. J. Hydrol., 359, 3-4, 225-234.

Aubert, D., Loumagne, C., Oudin, L., 2003. Sequential assimilation of soil moisture and streamflow data in a conceptual rainfall-runoff model. J. Hydrol., 280,145-161.

Baade, J., 1994. Geländeexperimente zur Verminderung des Schwebstoffaufkommens in landwirtschaftlichen Einzugsgebieten. Heidelberger Geographische Arbeiten 96, 215 p.

Bachmair, S., Weiler, M., 2011. New dimensions of hillslope hydrology. In: Levia, D.F., Carlyle-Moses, D., Tanaka, T. (Eds.): Forest Hydrology and Biogeochemistry: Synthesis of Past Research and Future Directions. Ecological Studies 216, pp. 455-481.

Bezirksregierung Köln, 2015. TIM-Online; http://www.timonline.nrw.de. Accessed 10 September 2015.

Blume, T., van Meerveld, H.J.I., 2015. From hillslope to stream: methods to investigate subsurface connectivity. Wiley Interdisciplinary Reviews: Water, 2, 3, 177-198.

Blume, T., Zehe, E., Bronstert, A., 2007. Rainfall-runoff response, event-based runoff coefficients and hydrograph separation. Hydrological Sciences Journal, 52, 5, 843-862.

Blume, T., Zehe, E., Bronstert, A., 2009. Use of soil moisture dynamics and patterns at different spatio-temporal scales for the investigation of subsurface flow processes. Hydrol. Earth Syst. Sci., 13, 1215-1233. DOI: 10.5194/hess-13-1215-2009.

Bogena, H.R., Herbst, M., Huisman, J.A., Rosenbaum, U., Weuthen, A., Vereecken, H., 2010. Potential of wireless sensor networks for measuring soil water content variability. Vadose Zone Journal, 9, 4, 1002-1013.

Brocca, L., Morbidelli, R., Melone, F., Moramarco, T., 2007. Soil moisture spatial variability in experimental areas of central Italy. J. Hydrol., 333, 356-373.
Brocca, L., Melone, F., Moramarco, T., Singh, V.P., 2009. Assimilation of observed soil moisture data in storm rainfallrunoff modelling. J. Hydrol. Eng., 14, 2, 153-165.

Brocca, L., Melone, F., Moramarco, T., Morbidelli, R., 2010. Spatial-temporal variability of soil moisture and its estimation across scales. Water Resour. Res., 46, W02516. DOI: 10.1029/2009WR008016.

Bronstert, A., Creutzfeldt, B., Graeff, T., Hajnsek, I., Heistermann, M., Itzerott, S., Jagdhuber, T., Kneis, D., Lück, E., Reusser, D., Zehe, E., 2012. Potentials and constraints of different types of soil moisture observations for flood simulations in headwater catchments. Nat. Hazards, 60, 879-914.

Casper, M., Gemmar, P., Gronz, O., Johst, M., Stüber, M., 2007. Fuzzy logic-based rainfall-runoff modelling using soil moisture measurements to represent system state. Hydrol. Sci. J., 52, 3, 478-490.

Chen, F., Chrow, W.T., Ryu, D., 2014. Dual forcing and state correction via soil moisture assimilation for improved rainfall-runoff modeling. J. Hydrometeor., 15, 1832-1848. DOI: http://dx.doi.org/10.1175/JHM-D-14-0002.1.

Chifflard, P., Zepp, H., 2008. Erfassung der zeitlichen Variabilität der Abflussbereitschaft eines Einzugsgebietes auf Grundlage von Bodenfeuchtemessungen. HyWa, 52, 3, 98-109.

Chifflard, P., Zepp, H., Schumann, A., 2004. Untersuchungen zum Einfluss der Vorfeuchte und des Reliefs auf die Abflussbildung. Forum für Hydrologie und Wasserbewirtschaftung, 05.04(2), 69-73.

Chifflard, P., Didszun, J., Zepp, H., 2008. Skalenübergreifende Prozess-studien zur Abflussbildung in Gebieten mit periglazialen Deckschichten (Sauerland, Deutschland). Grundwasser, 13, 1, 27-41.

Chifflard, P., Gall, S., Zepp, H., 2013. Regionalisierung der Oberbodenfeuchte im Südsauerländer Bergland (Deutschland, Nordrhein-Westfalen). Jahrbuch der Marburger Geographischen Gesellschaft 2013, pp. 146-165.

Deutscher Wetterdienst, 2004. Langjährige Klimadaten der Stationen Reichshof-Eckenhagen, Bergneustadt-Hüngrighausen und Attendorn-Listertalsperre. Offenbach.

Dikau, R., 1986. Experimentelle Untersuchungen zu Oberflächenabfluss und Bodenabtrag von Messparzellen und landwirtschaftlichen Nutzflächen. Heidelberger Geographische Arbeiten, 81, 195 p.

Engels, S., Marschner, B., Zepp, H., 2012. Analysing soil moisture reactions to precipitation for soil moisture regionalization. Geophys. Res. Abstr., 14, EGU2012-8472.

Fang, B., Lakshmi, V., 2014. Soil moisture at watershed scale: Remote sensing techniques. J. Hydrol., 516, 258-271.

Grabert, H., Hilden, H.D., 1972. Geologische Karte von NordrheinWestfalen 1:25000, Blatt 5012 Eckenhagen mit Erläuterungen. Geologisches Landesamt Nordrhein-Westfalen, Krefeld.

Grabs, T., Bishop, K., Laudon, H., Lyon, S.W., Seibert, J., 2012. Riparian zone hydrology and soil water total organic carbon (TOC): implications for spatial variability and upscaling of lateral riparian TOC exports. Biogeosciences, 9, 3901-3916.

Graeff, T., Zehe, E., Reusser, D., Luck, E., Schroder, B., Wenk, G., John, H., Bronstert, A., 2009. Process identification through rejection of model structures in a mid-mountainous rural catchment: observations of rainfall-runoff response, geophysical conditions and model inter-comparison. Hydrol. Process., 23, 5, 702-718. DOI: 10.1002/hyp.7171.

Graeff, T., Zehe, E., Blume, T., Francke, T., Schröder, B., 2012. Predicting event response in a nested catchment with generalized linear models and a distributed watershed model. Hydrol. Process., 26, 3749-3769.

Hedderich, J., Sachs, L., 2016. Angewandte Statistik. Methoden- 
sammlung mit R. Revised $14^{\text {th }}$ printing. Springer, Berlin, Heidelberg, 969 p. DOI: 10.1007/978-3-662-45691-0.

Hrnčír, M., Šanda, M., Kulasová, A., Císlerová, M., 2010. Runoff formation in a small catchment at hillslope and catchment scales. Hydrol. Process., 24, 2248-2256, DOI: 10.1002/hyp.7614.

Jacobs, J.M., Mohanty, B.P., Hsu, E.C., Miller, D., 2004. SMEX02: Field scale variability, time stability and similarity of soil moisture. Remote Sens. Environ., 92, 4, 436-446.

Jencso, K.G., McGlynn, B.L., Gooseff, M.N., Bencala, K.E., Wondzell, S.M., 2010. Hillslope hydrologic connectivity controls riparian groundwater turnover: Implications of catchment structure for riparian buffering and stream water sources. Water Resour. Res., 46, W10524.

Klaus, J., McDonnell, J.J., Jackson, C.R., Du, E., Griffiths, N.A., 2015. Where does streamwater come from in lowrelief forested watersheds? A dual-isotope approach. Hydrol. Earth Syst. Sci., 19, 125-135.

Kostka, Z., Holko, L., 2003. Analysis of rainfall-runoff events in a mountain catchment. In: Holko, L., Miklanek, P. (Eds.): Interdisciplinary Approaches in Small Catchment Hydrology: Monitoring and Research. IHP-VI Technical Documents in Hydrology No. 67, UNESCO, Paris, pp. 19-25.

Lakshmi, V., 2013. Remote sensing of soil moisture. ISRN Soil Science, 2013, Article ID 424178, 33 p. DOI: 10.1155/2013/424178.

Longobardi, A., Villani, P., Grayson, R.B., Western, A.W., 2003. On the relationship between runoff coefficient and catchment initial conditions. In: Proceedings of MODSIM 2003, pp. 867-872.

Massari, C., Brocca, L., Moramarco, T., Tramblay, Y., Lescot, J.F.D., 2014. Potential of soil moisture observations in flood modelling: Estimating initial conditions and correcting rainfall. Adv. Water Resour., 74, 44-53.

McGlynn, B.L., McDonnell, J.J. 2003. Quantifying the relative contributions of riparian and hillslope zones to catchment runoff. Water Resour. Res., 39, 11, 1310. DOI: 10.1029/2003WR002091.

McGlynn, B.L., Seibert, J., 2003. Distributed assessment of contributing area and riparian buffering along stream networks. Water Resour. Res., 39, 4, 1082. DOI: 10.1029/2002WR001521.

Moldenhauer, K.M., Heller, K., Chifflard, P., Hübner, R., Kleber, A., 2013. Influence of cover beds on slope hydrology. In: Kleber, A., Terhorst, B. (Eds.): Mid-Latitude Slope Deposits (Cover Beds). Elsevier, Amsterdam, 302 p.

Ojha, R., Morbidelli, R., Saltalippi, C., Flammini, A., Govindaraju, R.S., 2014. Scaling of surface soil moisture over heterogeneous fields subjected to a single rainfall event. J. Hydrol., 516, 21-36.

Parajka, J., Naemi, V., Blöschl, G., Wagner, W., Merz, R., Scipal, K., 2006. Assimilating scatterometer soil moisture data into conceptual hydrologic models at coarse scales. Hydrol. Earth Syst. Sci., 10, 353-368.

Pellenq, J., Kalma, J., Boulet, G., Saulnier, G.M., Wooldridge, S., Kerr, Y., Chehbouni, A., 2003. A disaggregation scheme for soil moisture based on topography and soil depth. J. Hydrol., 276, 112-127.

Penna, D., Tromp-van Meerveld, H.J.I., Gobbi, A., Borga, M., Dalla Fontana, G., 2011. The influence of soil moisture on threshold runoff generation processes in an alpine headwater catchment. Hydrol. Earth Syst. Sci., 15, 689-702.

Penna, D., Mantese, N., Hopp, L., Dalla Fontana, G., Borga, M., 2015. Spatio-temporal variability of piezometric response on two steep alpine hillslopes. Hydrol. Process., 29, 198-211.

Petrone, R.M., Price, J.S., Carey, S.K., Waddington, J.M., 2004. Statistical characterization of the spatial variability of soil moisture in a cutover peatland. Hydrol. Process., 18, 1, 41-52.
Pluntke, T., Jatho, N., Kurbjuhn, C., Dietrich, J., Bernhofer, C., 2010. Use of past precipitation data for regionalisation of hourly rainfall in the low mountain ranges of Saxony, Germany. Nat. Hazards Earth Syst. Sci., 10, 353-370.

Rinderer, M., Kollegger, A., Fischer, B.M.C., Stähli, M., Seibert, J., 2012. Sensing with boots and trousers - qualitative field observations of shallow soil moisture patterns. Hydrol. Process., 26, 26,4112-4120.

Schädel, W., 2006. Schritte zur Verbesserung der Hochwasserfrühwarnung mittels Online-Bodenfeuchtemessungen. Mitteilungen des Institutes für Wasser und Gewässerentwicklung, Bereich Wasserwirtschaft und Kulturtechnik der Universität Karlsruhe, Band 234, 186 p.

Schendzielorz, E., 2004. Channel morphology of the stream Brachtpe. Internal dynamic, human-caused impacts on the flood generation and requirements for renaturation. Unpublished Master Thesis. Ruhr-University of Bochum, Germany. (In German.)

Sidle, R.C., Tsuboyama, Y., Noguchi, S., Hosoda, I., Fujieda, M., Shimizu, T., 2000. Stormflow generation in steep forested headwaters: a linked hydrogeomorphic paradigm. Hydrol. Process., 14, 369-385.

Tague, C., Band, L., Kenworthy, S., Tenebaum, D., 2010. Plotand watershed-scale soil moisture variability in a humid Piedmont watershed. Water Resour. Res., 46, W12541. DOI: 10.1029/2009WR008078.

Tromp-Van Meerveld, I., McDonnell, J.J., 2006a. Threshold relations in subsurface stormflow: 1. A 147-storm analysis of the Panola hillslope. Water Resour. Res., 42, W02410. DOI: 10.1029/2004WR003778.

Tromp-Van Meerveld, I., McDonnell, J.J., 2006b. Threshold relations in subsurface stormflow: 2. The fill and spill hypothesis. Water Resour. Res., 42, W02411, DOI: 10.1029/2004WR003800.

Uchida, T., Asano, Y., Onda, Y., Mjyata, S., 2005. Are headwaters just a sum of hillslopes? Hydrol. Process., 19, 3251-3261.

Vereecken, H., Huisman, J.A., Pachepsky, Y., Montzka, C., van der Kruk, J., Bogena, H., Weihermüller, L., Herbst, M., Martinez, G., Vanderborght, J., 2014. On the spatio-temporal dynamics of soil moisture at the field scale. J. Hydrol., 516, 76-96.

Wagner, W., Blöschl, G., Pampaloni, P., Calvet, J.C., Bizzarri, B., Wigneron, J.P., Kerr, Y., 2007. Operational readiness of microwave remote sensing of soil moisture for hydrologic applications. Nord Hydrol., 38, 1, 1-20.

Western, A., Zhou, S.L., Grayson, R.B., McMahon, T.A., Blöschl, G., Wilson, D.J., 2004. Spatial correlation of soil moisture in small catchments and its relationship to dominant spatial hydrological processes. J. Hydrol., 286, 1-4, 113-134.

Woods, R.A., Sivapalan, M., Robinson, J.S., 1997. Modeling the spatial variability of subsurface runoff using the topographic index. Water Resour. Res., 33, 5, 1061-1073.

Zehe, E., Blöschl, G., 2004. Predictability of hydrologic response at the plot and catchment scales: Role of initial conditions. Water Resour. Res., 40, W10202, DOI: 10.1029/2003WR002869.

Zehe, E., Graeff, T., Morgner, M., Bauer, A., Bronstert, A., 2010. Plot and field scale soil moisture dynamics and subsurface wetness control on runoff generation in a headwater in the Ore Mountains. Hydrol. Earth Syst. Sci., 14, 873-889.

Zillgens, B., Merz, B., Kirnbauer, R., Tilch, N., 2007. Analysis of the runoff response of an alpine catchment at different scales. Hydrol. Earth Syst. Sci., 11, 1441-1454.

Received 8 December 2016 Accepted 16 May 2017 